$\begin{array}{r}\begin{array}{l}\text { Interdisciplinary Contexts of Special Pedagogy } \\ \text { NUMER 24/2019 }\end{array} \\ \text { AGNIESZKA NYMŚ-GÓRNA } \\ \text { Adam Mickiewicz University, Poznań } \\ \hline\end{array}$

\title{
Prisoners with disabilities in the Polish penitentiary system
}

\begin{abstract}
Agnieszka Nymś-Górna, Prisoners with disabilities in the Polish penitentiary system. Interdisciplinary Contexts of Special Pedagogy, no. 24, Poznań 2019. Pp. 177-187. Adam Mickiewicz University Press. ISSN 2300-391X. DOI: https://doi. org/10.14746/ikps.2019.24.10

The article deals with the subject of both intellectually and physically disabled prisoners. It describes people with disabilities, the functioning of the therapeutic system for prisoners and the situation of detaining people with disabilities in penitentiary isolation. The text aims to sensitise this issue and to identify this problem in the organisation of the penitentiary system.
\end{abstract}

KEY WORDS: disability, prison, rehabilitation, therapeutic system.

A certain part of society can relate crime to controversial issues. These topics are frequently linked to various kinds of dysfunctions, deficits and pathologies. However, should one give in to the stereotypical way of thinking, it might be that the real problems of the other person would not be noticed. If additionally, the criminal turns out to be a disabled person, whose difficulties are compounded, it is easier to enter the path of conflict with the law.

Many scientific disciplines and fields deal with disabilities. One could name for instance education science, psychology, sociology, medicine, catholic social teachings or the law. It is thus not an une- 
quivocal and universal concept. It is most commonly analysed within the context of a specific field of science ${ }^{1}$.

According to the Polish act of August 27th, 1997, on vocational and social rehabilitation and the employment of disabled persons ${ }^{2}$, people with disabilities are individuals, "the physical, psychological or mental condition of whom hinders, limits or prevents permanently or periodically the fulfilment of social roles, and in particular the ability to perform professional work". Disability in the legal sense is determined on the basis of a certificate issued by a specific authority. This certificate is substantiated by the opinion of a committee composed of a range of specialists ${ }^{3}$. An interesting approach is included in the International Classification of Functioning, Disability and Health (ICF) published by the World Health Organisation. Pursuant to the mentioned ICF, disability is

an umbrella term for impairments, activity limitations and participation restrictions. It denotes the negative aspects of the interaction between an individual (with a health condition) and that individual's contextual factors (environmental and personal factors) ${ }^{4}$.

Pursuant to the ICF, disability is a multidimensional phenomenon that stems from a range of interactions between the individual and the physical and social environment around man 5 . Perhaps it would be worthwhile to ponder the possibility of usage of this classification for resocialisation purposes. The International classification of functioning, disability and health, just like the diagnostic process of underage, juvenile or adult perpetrators of crimes is

${ }^{1}$ M. Giełda, Pojęcie niepetnosprawności, [in:] Prawno-administracyjne aspekty sytuacji osób niepetnosprawnych w Polsce, ed. by M. Giełda, R. Raszewska-Skałecka, Wrocław 2015, p. 20.

2 Polish Journal of Laws of 1997, no. 123, item no. 776, art. 1.

${ }^{3}$ M. Karaś, Niepetnosprawność, od spojrzenia medycznego do społecznego i Disability Studies, „Przegląd Prawniczy, Ekonomiczny i Społeczny” 2012, no. 4, p. 28.

${ }^{4}$ International classification of functioning, disability and health (ICF), 2001, p. 221.

${ }^{5}$ Ibidem, p. 242. 
based primarily on properties that are characteristic for a given state of affairs, considering them from the perspective of individual events and environmental influences. In the diagnostic process (and this is presented in the same manner in the ICF), specialists do not limit themselves to fixed categories, but the entire case is considered within a specific context.

It is worth noting that according to the results of the Polish national Census of People and Housing of the year 2011 as conducted by Statistics Poland, the number of people with disabilities in Poland amounted to $4,697.5$ thousand, meaning, $12.2 \%$ of the population. To compare, in the year 2002 this number was 14.3\% (5,456.7 thousand people $)^{6}$. Considering the fact that this number is significant, activity must be undertaken that will be aimed at attracting attention in politics to people with disabilities, to people experiencing difficulty running their everyday lives, at any age - both younger as well as older ones (who will grow in numbers due to the ageing of the general population). In addition, noticeable are long-term disabilities, a fact that policies concerning the disabled should also be sensitive to ${ }^{7}$.

Presently (as of January 31st, 2018), prisons and custody facilities in Poland are holding 74,896 people, including 2954 women ${ }^{8}$. Within the prison population, particular attention should be paid to prisoners who are disabled, both physically as well as intellectually. In general, disabled people have been in recent time sent to prison for increasingly serious crimes. Beside theft, assaults or fraud, they have also been convicted for leading organised crime groups ${ }^{9}$.

6 Polish National Census, Statistics Poland, https://stat.gov.pl/cps/rde/xbcr/ gus/lud_raport_z_wynikow_NSP2011.pdf [access: 09.03.2018].

${ }^{7}$ K. Slany, Osoby niepetnosprawne w świetle Narodowego Spisu Powszechnego Ludności i Mieszkań z 2011 r. - wybrane aspekty, „Niepełnosprawność - zagadnienia, problemy, rozwiązania" 2014, no. II (11), p. 61.

8 Polish Prison Service, http://www.sw.gov.pl/strona/statystyka-biezaca [access: 09.03.2018].

${ }_{9}$ E. Jarecka, R. Wolak, Niepetnosprawność osadzonych - problem czy wyzwanie polskiego więziennictwa, [in:] Misja stużby więziennej wobec aktualnej polityki karnej i ocze- 
The issue of disability is closely related to healthcare. This issue is governed with respect to penal facilities and investigative custody facilities by acts of law (in particular the Polish Executive Penal Code), regulations (e. g. the Regulation of the Polish Minister of Justice of October 31st, 2003, on detailed rules, scope and mode of provision of health care to imprisoned persons by health care facilities for imprisoned persons, and regulation of the Polish Minister of Justice and the Minister of Health of September 10th, 2003, on the detailed rules, scope and mode of cooperation of health care facilities with the health care at penal facilities and investigative custody facilities in order to provide health care to imprisoned persons), as well as provisions of international law (e. g. the Universal Declaration of Human Rights or European Prison Rules, primarily in part III). The injured prisoners (including those with mental disabilities) as well as disabled prisoners) mostly direct their complaints to the Helsinki Foundation for Human Rights. Most commonly, they complain about the operation of the prison health care system, and less frequently on the conditions of their imprisonment ${ }^{10}$.

Any prisoner may serve their prison time within one of three systems of imprisonment: an ordinary one, a therapeutic one or one with programme influence. In the ordinary system, the prisoner may make use of employment available at the relevant prison facility as well as learning, cultural and education as well as sports activities ${ }^{11}$. Underage prisoners obligatorily serve their time In the programme influence system. Adult prisoners may also make use of it, who upon having the assumptions of the project presented to them would consent to participation in its development and later execution. If the prisoner would not execute their tasks, they are transferred to the ordinary system. The designed influence takes

kiwań społecznych: IV Kongres Penitencjarny, ed. by W. Ambrozik, H. Machel, P. Stępniak, Kalisz 2008, p. 692.

${ }^{10} \mathrm{~K}$. Korona, Sytuacja osób niepetnosprawnych przebywających w polskich w polskich zaktadach karnych, "Zeszyty Naukowe WSSP” 2013, vol. 16, p. 16.

${ }^{11}$ Polish Act of June 6th, 1997 - Executive Penal Code, art. 98, Polish Journal of Laws 2017.0.665. 
into account primarily: employment, education, contacts with next of kin of the prisoner, arrangement of free time as well as other issues that are necessary to prepare the prisoner for later return to society. The programmes may be modified as needed. They are also periodically evaluated ${ }^{12}$. In the therapeutic system, in turn, time is served y prisoners with non-psychotic mental disabilities, including criminals sentenced for crimes against sexual freedom (art. 197-203 of the Polish Penal Code), the intellectually disabled, with addictions (in particular to alcohol or other intoxicants or psychotropic substances) as well as prisoners with physical disabilities, if their current health condition would require specialist work (including psychological, medical or rehabilitation care $)^{13}$. When a sentence is served in this system, it takes into account during work with the prisoner the prevention of expansion of the pathological personal traits, the reestablishment of psychological balance as well as the development of capacity of social coexistence and preparation for independence after they leave the correction facility. The prison time is adapted in such cases, among others, to the health care needs or the sanitary and hygiene recommendations. If it is concluded that the prisoner would not require any more specialist influence, they are transferred to the ordinary or the programme influence system ${ }^{14}$. It is worth noting that the provisions of the Executive Penal Code do not foresee the possibility of serving prison time outside of the systems ${ }^{15}$.

To serve time in the therapeutic system means to remain in wards with individual specialisations so that these influence could to the greatest possible extent be adapted to the needs of prisoners.

12 Polish Act of June 6th, 1997 - Executive Penal Code, art. 95, Polish Journal of Laws 2017.0.665

13 Polish Act of June 6th, 1997 - Executive Penal Code, art. 96 par. 1, Polish Journal of Laws 2017.0.665

14 Polish Act of June 6th, 1997 - Executive Penal Code, art. 97, Polish Journal of Laws 2017.0.665

15 P. Stępniak, System programowanego oddziatywania w opiniach więźniów, "Archiwum Kryminologii" 2009, vol. XXXI, p. 265. 
In therapeutic wards various activity forms are implemented, such as e. g. programmes facilitating cognitive and social activity, interpersonal competence training, relaxation training or mobility encouragement. Beside this, the prisoners may make use of cultural and educational classes, art classes, sports classes, occupational therapy or employment ${ }^{16}$. In addition, due to upgrade changes, the list of planned purposes of prisons and investigative custody facilities in Poland is being constantly updated ${ }^{17}$, so that prisoners with special needs could obtain as individualised and professional aid where they are serving their time, as possible.

In the previous year (as of December 31st, 2017), the number of prisoners qualified at therapeutic wards and remaining there was 3229, of which 180 were women ${ }^{18}$. There were 1553 persons with non-psychotic psychological disorders or intellectual disabilities, with 326 persons diagnosed with sexual preference disorders ${ }^{19}$. Persons addicted to intoxicants or psychotropic substances numbered 509, and those addicted to alcohol $-1167^{20}$. Persons qualified in therapeutic wards and remaining outside of these numbered 825 , including 39 women $^{21}$. The reasons for prisoners remaining outside of these wards are quite numerous - from treatment all the way to waiting for transport, along with many other, individual difficulties. Within the prison population, a further group is distinguished those qualified to a therapeutic system outside of the ward, num-

${ }^{16}$ A. Purczyński, Wybrane aspekty funkcjonowania oddziału terapeutycznego dla skazanych z niepsychotycznymi zaburzeniami psychicznymi lub upośledzonych umysłowo i oddziału terapeutycznego dla skazanych uzależnionych od środków odurzających lub psychotropowych w zakładzie karnym w Rawiczu, [in:] Pomoc postpenitencjarna w kontekście strategii dziatań resocjalizacyjnych, ed. by B. Skafiriak, Kraków 2007, pp. 119-126.

17 See Purpose of prisons and investigative custody facilities according to their status as of February 19th, 2018, http:/ / www.sw.gov.pl/strona/statystyka-przeznaczenie-zki-as [access: 09.03.2018].

18 Polish Prison Service Statistics, http://www.sw.gov.pl/strona/statystykaroczna [access: 09.03.2018].

19 Ibidem.

20 Ibidem.

${ }^{21}$ Ibidem. 
bering in total 688 (including 58 women) ${ }^{22}$. This group included nobody with non-psychotic psychological deficiencies or intellectual disabilities ${ }^{23}$. There were 220 persons addicted to intoxicants or psychotropic substances, and 467 persons addicted to alcohol ${ }^{24}$. Only one person with a physical disability was qualified for this type of influence ${ }^{25}$.

Therapy was included among penitentiary and therapeutic modes of influence. During their execution, primarily the deficits requiring intervention are taken into account, which deficits could be one of the reasons for the committed crime ${ }^{26}$. Therapy is provided in this regard as a component of penitentiary resocialisation, or the corrective process of behaviour utilised at penal facilities and investigative custody facilities, as well as correctional facilities for minors ${ }^{27}$.

Persons with psychological disabilities have the most extensive difficulty of adaptation at penitentiary facilities, whereby it must be stated that isolation itself is already a difficult situation to begin with $^{28}$. Moreover, sadly, persons with intellectual disabilities can be abused by criminals. A disturbed critical evaluation system and ease of influence could cause the fact that a criminal could make direct contact with a person with an intellectual disability and then abuse them for their own purposes in a fraudulent manner ${ }^{29}$.

22 Ibidem.

${ }^{23}$ Ibidem.

${ }^{24}$ Ibidem.

${ }^{25}$ Ibidem.

${ }^{26}$ Regulation no. 19/ 16 of the General Director of the Polish Prison Service of April 14th, 2016, on detailed rules of execution and organisation of penitentiary work and the scopes of activities of officers and employees of penitentiary and therapeutic wards as well as penitentiary wards, par. 3 .

${ }^{27} \mathrm{H}$. Machel, Wprowadzenie do pedagogiki penitencjarnej, Wydawnictwo Uniwersytetu Gdańskiego, Gdańsk 1994, p. 15.

${ }^{28}$ K. Korona, op. cit., p. 14.

${ }^{29}$ M. Ciosek, Psychologia sądowa i penitencjarna, Wydawnictwo Prawnicze Lexis Nexis, Warszawa 2001, p. 210. 
Even though it seems that persons with intellectual disabilities as well as psychological disabilities should not find themselves in penitentiary isolation, however the Polish prison system knows such cases. Isolation may primarily worsen the functioning of persons with such disturbances that was their condition up to that point. In certain cases, symptoms of psychological disturbances during the conducted tests are still barely noticeable, however the situation of isolation would cause the illness to worsen and the symptoms to become ever more clear. In addition, as far as intellectual disability at its early stages goes, any developmental deficiencies should be the cause of execution of thorough diagnostics (primarily psychological and psychiatric ones) the moment such a person would commit a crime ${ }^{30}$.

Disabled persons should have access to rehabilitation and treatment at the prison facility or the option of using such services outside of the facility. However, in such a case, social indignation could be the case ${ }^{31}$ primarily due to the fact that prisoners should primarily serve their prison time (and due to the isolation - experience a range of difficulties), instead of receiving such 'privileges'. For a disabled person, therapeutic and rehabilitation activity are no privilege, but a necessity, and limiting access to them could cause long-term negative consequences in all aspects of human life. Sensitising society in this regard could become key in order to design influences, including in terms of cooperation with external entities.

Disabled persons can also actively participate in penitentiary programmes. Annually, the Penitentiary Office of the Central Management of the Polish Prison Service organises the Polish Country-

$30 \mathrm{~J}$. Heitzman, Niepetnosprawni intelektualnie i chorzy psychicznie w jednostkach penitencjarnych, [in:] Osoby z niepetnosprawnościa intelektualna lub psychiczna osadzone w jednostkach penitencjarnych, ed. by E. Dawidziuk, M. Mazur, Warszawa 2017, pp. 17-21.

31 See: J. Janik, Więźniowie obstugiwani sa poza kolejnością. Pacjent nie odbywający kary poczeka na wizyte..., http://www.rynekzdrowia.pl/Finanse-i-zarzadzanie/Wiez niowie-obslugiwani-sa-poza-kolejnoscia-Pacjent-nie-odbywajacy-kary-poczeka-nawizyte-amp-8230,119491,1.html [access: 27.10.2018]; K. Nowosielska, Prawa pacjenta: Więzień u lekarza bez kolejki, https://www.rp.pl/artykul/1073971-Prawa-pacjenta-Wiezien-u-lekarza-bez-kolejki.html [access: 27.10.2018]. 
wide Competition for a Resocialisation Programme Facilitating Social Readaptation for Prisoners. The competition takes place under the patronage of the General Director. There are three categories, each with a prize: programmes aimed at juveniles, older prisoners $(60+)$ or disabled prisoners as well as those serving life or 25 year sentences ${ }^{32}$. Significant is the fact that the group of prisoners with disabilities was distinguished as one of the target groups, as thanks to this, new programmes are created that may be aimed at the special needs of this prisoner group.

In addition, one should reflect on the level, to which one could be able to engage themselves in the offered resocialisation and penitentiary activities when their basic needs are not satisfied. To what extent can penitentiary resocialisation be reconciled with health treatment and rehabilitation so that these processes would be complementary and as effective as possible?

Penitentiary facilities are perceived to be very unfriendly places. To remain at them means to be drawn away from normalisation of life $^{33}$. The needs of prisoners with disabilities differ somewhat from the needs of other prisoners. Officers of the Polish Prison Service will have more work on their hands. The situation continues to improve, however, dilemmas and difficulties continue to emerge that require constructive solutions. Diverse programmes are being implemented, the assumptions of which focus on the support of historic efforts. Their results are meant to encourage further initiatives.

\section{Bibliography}

Braun P., Osoba niepełnosprawna w izolacji penitencjarnej, „Niepełnosprawność zagadnienia, problemy, rozwiązania" 2013, no. II (7).

32 Central Management of the Polish Prison Service, Media Communications Team, Results of the competition for the best resocialisation programme, https:/ /www. sw.gov.pl/aktualnosc/centralny-zarzad-sluzby-wieziennej-wyniki-konkursu-na-naj lepszy-program-resocjalizacji\%20rozsrzygni\% C4\%99ty [access: 28.10.2018].

33 P. Braun, Osoba niepetnosprawna w izolacji penitencjarnej, „Niepełnosprawność - zagadnienia, problemy, rozwiązania” 2013, no. II(7), p. 137. 
Ciosek M., Psychologia sądowa i penitencjarna, Wydawnictwo Prawnicze Lexis Nexis Warszawa 2001.

Giełda M., Pojęcie niepetnosprawności, [in:] Prawno-administracyjne aspekty sytuacji osób niepetnosprawnych w Polsce, ed. by M. Giełda, R. Raszewska-Skałecka, Wrocław 2015.

Heitzman J., Niepetnosprawni intelektualnie $i$ chorzy psychicznie w jednostkach penitencjarnych [in:] Osoby z niepełnosprawnością intelektualną lub psychiczną osadzone w jednostkach penitencjarnych, ed. by E. Dawidziuk, M. Mazur, Warszawa 2017.

International classification of functioning, disability and health (ICF), WHO 2001.

Jarecka E., Wolak R., Niepetnosprawność osadzonych - problem czy wyzwanie polskiego więziennictwa, [in:] Misja stużby więziennej wobec aktualnej polityki karnej i oczekiwań społecznych: IV Kongres Penitencjarny, ed. by W. Ambrozik, H. Machel, P. Stępniak, Kalisz 2008.

Karaś M., Niepetnosprawność, od spojrzenia medycznego do społecznego i Disability Studies, „Przegląd Prawniczy, Ekonomiczny i Społeczny” 2012, no. 4.

Korona K., Sytuacja osób niepetnosprawnych przebywających w polskich zakładach karnych, "Zeszyty Naukowe WSSP” 2013, vol. 16.

Machel H., Wprowadzenie do pedagogiki penitencjarnej, Wydawnictwo Uniwersytetu Gdańskiego, Gdańsk 1994.

Purczyński A., Wybrane aspekty funkcjonowania oddziału terapeutycznego dla skazanych $z$ niepsychotycznymi zaburzeniami psychicznymi lub upośledzonych umystowo i oddziału terapeutycznego dla skazanych uzależnionych od środków odurzających lub psychotropowych w zakładzie karnym w Rawiczu, [in:] Pomoc postpenitencjarna w kontekście strategii działań resocjalizacyjnych, ed. by B. Skafiriak, Kraków 2007.

Slany K., Osoby niepetnosprawne w świetle Narodowego Spisu Powszechnego Ludności i Mieszkań z 2011 r. - wybrane aspekty, "Niepełnosprawność - zagadnienia, problemy, rozwiązania" 2014, no. II (11).

Stępniak P., System programowanego oddziaływania w opiniach więźniów, "Archiwum Kryminologii" 2009, vol. XXXI.

Acts of law

Polish Act of August 27th, 1997, on vocational and social rehabilitation and the employment of disabled persons, Polish Journal of Laws of 1997, no. 123, item no. 776 .

Polish act of June 6th, 1997 - Executive Penal Code, Polish Journal of Laws 2017.0.665.

Regulation no. 19/ 16 of the General Director of the Polish Prison Service of April 14th, 2016, on detailed rules of execution and organisation of penitentiary work and the scopes of activities of officers and employees of penitentiary and therapeutic wards as well as penitentiary wards. 
Netography

Janik J., Więźniowie obstugiwani sa poza kolejnością. Pacjent nie odbywający kary poczeka na wizytę..., http://www.rynekzdrowia.pl/Finanse-i-zarzadzanie/Wiezniowieobslugiwani-sa-poza-kolejnoscia-Pacjent-nie-odbywajacy-kary-poczeka-na-wizy te-amp-8230,119491,1.html [access: 27.10.2018]

Polish National Census, Statistics Poland, https://stat.gov.pl/cps/rde/xbcr/gus/ lud_raport_z_wynikow_NSP2011.pdf [access: 09.03.2018].

Nowosielska K., Prawa pacjenta: Więzień u lekarza bez kolejki, https://www.rp.pl/ artykul/1073971-Prawa-pacjenta--Wiezien-u-lekarza-bez-kolejki.html [access: 27.10.2018].

Polish Prison Service, http://www.sw.gov.pl/strona/statystyka-biezaca [access: 09.03.2018].

Purpose of prisons and investigative custody facilities according to their status as of February 19th, 2018, http://www.sw.gov.pl/strona/statystyka-przeznaczenie-zk-i-as [access: 09.03.2018].

Polish Prison Service Statistics, http://www.sw.gov.pl/strona/statystyka-roczna [access: 09.03.2018].

Central Management of the Polish Prison Service, Media Communications Team, Results of the competition for the best resocialisation programme, https://www.sw. gov.pl/aktualnosc/centralny-zarzad-sluzby-wieziennej-wyniki-konkursu-na-naj lepszy-program-resocjalizacji\%20rozsrzygni\%C4\%99ty [access: 28.10.2018]. 